Nevşehir Bilim ve Teknoloji Dergisi Cilt 6(2) 571-579 2017

DOI: 10.17100/nevbiltek.354629

URL: http://dx.doi.org/10.17100/nevbiltek.354629

\title{
Nevşehir Pomza Endüstrisi’nin Genel Değerlendirilmesi
}

\author{
Ahmet ORHAN $^{1, *}$, İsmail DINÇER ${ }^{1}$, Mutluhan AKIN $^{1}$, Serap ÇOBAN ${ }^{2}$ \\ ${ }^{1}$ Nevşehir Hacı Bektaş Veli Üniversitesi, Jeoloji Mühendisliği Bölümü, Nevşehir \\ ${ }^{2}$ Nevşsehir Hacı Bektaş Veli Üniversitesi, İktisadi ve İdari Bilimler Fakültesi, İktisat Bölümü, Nevşehir \\ $\ddot{O} z$
}

$\mathrm{Bu}$ çalışmada, Nevşehir ilinin önemli ekonomik kaynaklarından biri olan pomza endüstrisinin genel durumunu ve önemli problemlerini belirlemek için sektörün paydaşlarıyla ikili görüşmeler ve arazi çalışmaları gerçekleştirilmiştir. Ülkemiz yaklaşık 18 milyar ton olan dünya pomza rezervinin \%15.8'ine sahip olurken, Nevşehir ise ülke rezervinin \%17'sine sahiptir. Aynı zamanda Türkiye pomza madeni işletme ruhsatlarının yaklaşık \%20'sine sahip olan Nevşehir bölgesi, bu açıdan birinci sırada yer almaktadır. Nevşehir pomza endüstrisi genel olarak iç piyasaya yönelik olup, son yıllarda üretim hacmi hızla gelişmektedir. Buna karşın ihracat hacmi, yüksek nakliye giderleri, sektör tarafından düşük standartlı ürünlerin varllğı, yapı malzemesi dışında (tekstil, kimya vb.) alternatif ürünlerin azlığı gibi nedenlerden dolayı azalan bir eğilim göstermektedir. Üreticilerin \%63’ü herhangi bir Ar-Ge çalışması yapmazken, bölgedeki üniversiteler ve pomza endüstrisinin işbirliği yok denilecek düzeydedir. Tüm bunlar göz önünde bulundurulduğunda Nevşehir pomza sektörünün problemleri şu şekilde özetlenebilir. Bunlar, ürün ve kalite standardizasyonu konusunda anlayış eksikliği, pazarlama noktasında bilinçsizlik, üniversite-sanayi işbirliğinin sınırlı düzeyde olması, Ar-Ge çalışmalarının yetersizliği, kalifiye eleman eksikliği, haksız rekabetin neden olduğu düşük fiyat, ortak hareket etme kültürünün yetersizliği ve katma değeri düşük ürünlerin sektöre hâkim olması olarak tespit edilmiştir.

Anahtar Kelimeler: Pomza, Nevşehir, bims, yapı malzemesi, Ar-Ge

\section{General Overview of Pumice Industry in Nevşehir}

\section{Abstract}

The pumice industry is one of the most crucial economic incomes in Nevşehir province. Thus, field studies and interviews with industry stakeholders were carried out to determine the general condition and the main problems of the pumice industry. World pumice reserves are estimated to be around 18 billion tons while Turkey has $15.8 \%$ of world pumice reserves. Accordingly, Nevşehir has also a substantial potential (about $17 \%$ of Turkey pumice reserves) due to its geological structure. At the same time, $20 \%$ of pumice mining operation licenses in Turkey are assigned in Nevşehir leading to the first rank with this rate. The pumice industry of Nevşehir is mainly domestic and it is quickly developing in recent years. On the contrary, a decreasing trend has been reported in the export volume due to very high transportation costs, poor quality standards of the suppliers in the sector and less alternative fields of use rather than construction (e.g. textile, chemistry etc.). $63 \%$ of pumice operating companies do not invest any money for R\&D. At the same time, the cooperation between university and pumice industry is extremely inadequate. Eventually, the major problems of the pumice industry in Nevşehir can be summarized as; insufficient understanding of the product and quality standardization, unconsciousness in marketing and promotion, limited cooperation of university and industry, limited R\&D activities, lack of qualified staff, low prices due to unfair competition, lack of cooperative work habit and low quality products dominating the sector.

Keywords: Pumice, Nevşehir, bims, construction material, R\&D

\footnotetext{
*e-mail: ahmet.orhan@nevsehir.edu.tr
} 


\section{Giriş}

Nevşehir ili metalik madenler yönünden önemli bir varlığa sahip olmamasına rağmen, jeolojik yapısından dolayı endüstriyel hammaddeler açısından büyük bir zenginliğe sahiptir. Bölgedeki yoğun volkanik faaliyetler sonucunda oluşan volkanik ürünler (Pomza, Perlit), Nevşehir'in önemli ekonomik zenginlikleri arasında yer almaktadır. Resmi olarak elde edilebilen verilere göre, 18 milyar $\mathrm{m}^{3}$ civarında olan dünya pomza rezervlerinin yaklaşı \% 15.8 'ine sahip olan ülkemiz, pomza madeni potansiyeli açısından çok önemli bir konuma sahiptir. Ülkemizde ise pomza madeninin büyük bir bölümü Bitlis, Kayseri ve Nevşehir illerinde bulunmakta olup, Nevşehir toplam ülke rezervinin \% 17'sine sahiptir. Bu oran ile Nevşehir, pomza rezervi bakımından üçüncü sırada yer almakla birlikte, illere göre işletme ruhsatı açısından değerlendirildiğinde, birinci sırada yer almaktadır.

Pomza terimi İtalyanca bir sözcük olup, değişik dillerde farklı sözcüklerle adlandırılmaktadır. Fransızca'da Ponce, İngilizce'de iri taneli olanına Pumice, ince taneli olanına ise Pumicite, Almanca'da iri tanelisine Bims, ince tanelisine Bimstein adı verilmektedir. Türkçe'de ise sünger taşı, köpüktaşı, hışırtaşı, nasırtaşı, küvek, kısır gibi adlarla anılmaktadır. Diğer dillerin ve teknoloji ithalinin etkisiyle Türkçe'ye Pomza, Ponza, Bims, Pumis ve Pumisit terimleri yerleşmiştir [1]. Volkanik bir ürün olan pomza yataklarının Nevşehir ve civarında oluşmasına şüphesiz bölgenin sahip olduğu jeolojik yapı neden olmuştur. Pomzanın, dünyada ve ülkemizde ağılıklı olarak inşaat sektöründe hafif yapı malzemesi olarak kullanımın yanında peyzaj mimarisi, tekstil sanayisi, tarım ve kimya alanları gibi birçok farklı alanda kullanım imkânı bulunmaktadır. Pomzanın inşaat sektöründe kullanımı dünyada \% 70 civarında iken ülkemizde ise bu oran \% 80'i aşmış durumdadır. Pomzanın sahip olduğu fiziksel ve kimyasal özellikler inşaat sektöründe aranan bir malzeme olmasının en önemli nedenidir. Sahip olduğu bu özellikler 1sı, ses ve hafiflik açısından yapı malzemelerinde iyi sonuçlar vermektedir. Son yıllarda depremselliğin, gürültü kirliliğinin ve enerji tüketiminin dünya üzerinde hızla artış göstermesinden dolayı pomza gibi dayanıklı, hafif, ses ve 1sı geçirgenliği az olan malzemelerin inşaat sektöründe kullanımı gün geçtikçe artmaktadır. Nevşehir bölgesindeki asidik pomzalar, birim hacim ağırlıklarının düşük, porozite ve 1sı-ses izolasyonunun yüksek, atmosferik şartlara dayanıklı, kolay işlenebilir ve yüksek puzzolanik aktiviteye sahip olmalarından dolayı, inşaat sektöründe hafif yapı elemanı olarak yoğun bir şekilde tercih edilmektedir [2].

Dünyada bilimsel ve teknolojik gelişmeler baş döndürücü bir hızla ilerlemektedir. Ülkeler bu teknolojik gelişmelere ayak uydurmak, hızla gelişmekte olan bu teknolojik arenada yerlerini alabilmek ve rekabet güçlerini artırmak için yatırım yapmak zorundadırlar. Ülkelerin teknolojik gelişmeler sağlayabilmesi, kullanılabilir bilginin üretilmesine ve disiplinler arası çalışmalara bağlıdır. Bu kapsamda Nevşehir ili için önem arz eden doğal malzemelerden pomzanın ve pomzadan üretilen ürünlerin mevcut teknik özelliklerinin belirlenmesi ve iyileştirilmesi sektör için önemli konulardan biridir. Ayrıca yapılacak olan Ar-Ge çalışmaları ile katma değeri yüksek alternatif ürünler üretilmesi sektör açısından oldukça önemli olup, sektörün hem ulusal hem de uluslararası ölçekte rekabet etme gücü arttıracaktır. Böylece, kaynakların daha efektif şekilde kullanılmasına imkân tanınmış olacak ve buna bağlı olarak da gelir ve istihdam oranlarının artışı sağlanabilecektir. Bu çalışmada, 2015 yılında sektörün mevcut durumunu ortaya koymak üzere yapılan anket çalışmasının sonuçları ve mevcut literatürden elde edilen verilere yer verilmiş olup, buna göre sektörün mevcut durumu, sektörün sorunları ve çözüm önerileri tartışılmıştır. 


\section{Nevşehir Pomza Madenciliği}

Ülkemizde bulunan pomza sahaları içerisinde en iyi kalitede ve inşaat sektörü dışında en fazla kullanım alanı bulan pomza çeşidi Nevşehir ili sınırları içerisinde bulunmaktadır. Aynı zamanda pomza ihracatının büyük bölümü Nevşehir'den yapılmaktadır. Nevşehir ilinde, il merkezi, Ürgüp, Derinkuyu ve Acıgöl arasında kalan bölgede çok sayıda işletilen ve işletilmiş pomza yatakları yer almaktadır. Bu yatakların toplam rezervi yaklaşık 450 milyon $\mathrm{m}^{3}$ civarındadır [3]. Nevşehir ili ülkemiz pomza rezervinin \%17'sine sahip olup, bu oran ile Bitlis ve Kayseri’nin ardından üçüncü sırada yer almaktadır. Maden İşleri Genel Müdürlüğünün (MİGEM) kayıtlarına göre pomza madenine ait işletme ruhsatı sayısı 2014 yılında tüm Türkiye için 114 adet olup, bunların 23 tanesi Nevşehir iline aittir. Bu sayıyla Nevşehir işletme ruhsatları arasında 2012 yılında \%15'lik bir orana sahip iken, 2014 yılında bu oran \%20'ye yükselmiş ve iller arasında birinci sırada yer almıştır (Şekil 1).

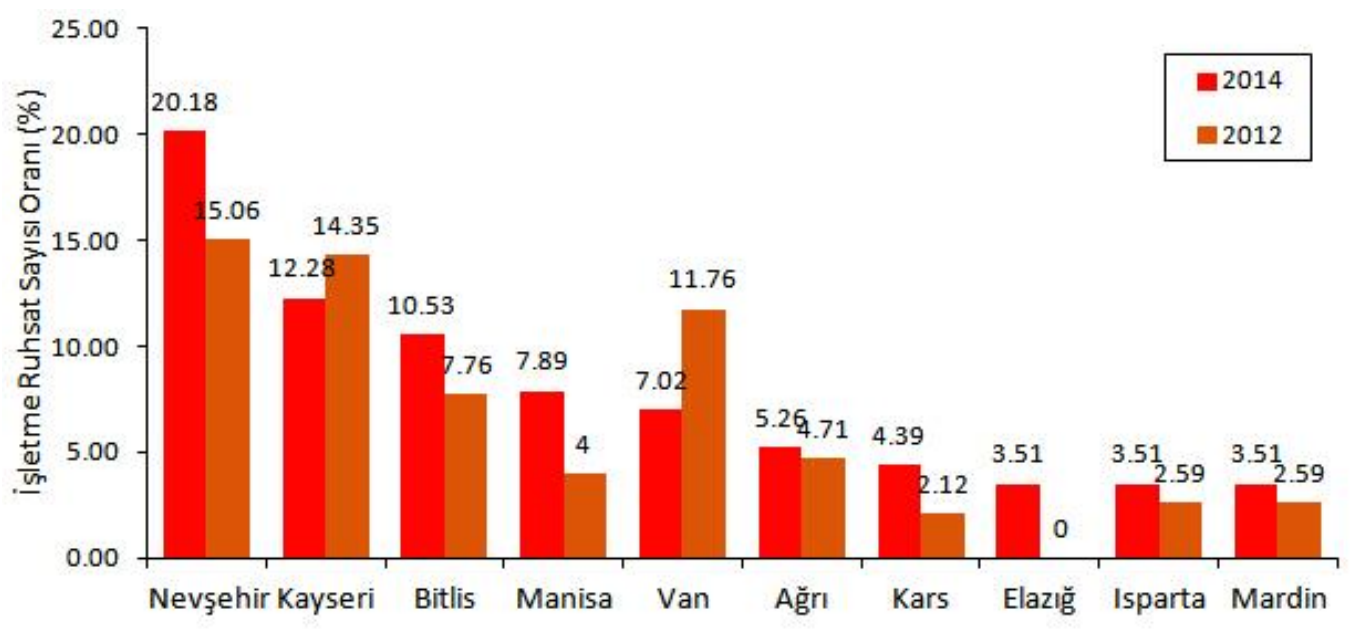

Şekil 1. İllere göre pomza işletme ruhsat sayılarının değişimi [4]

Nevşehir ilinde pomza üretimine baktığımızda, herhangi bir zenginleştirme yapılmadan yani tüvenan üretim miktarları göz önünde bulundurulduğunda, 2010 yılından itibaren sürekli bir artış göstermesine rağmen 2013 yılında bir azalma meydana gelmiştir. 2011 ve 2012 yıllarında sırasıyla bir önceki yıla göre artış miktarı \%53 ve \%27 olarak gerçekleşirken, 2013 yılında tüvenan üretimi 757.907 ton olarak gerçekleşmiş ve bir önceki yıla göre \%24'lük bir düşüş meydana gelmiştir. Pomza maden işletmelerinin Maden İşleri Genel Müdürlüğü’ne yapmış oldukları beyanlara göre 2014 yılında toplam tüvenan pomza üretimi 1.632.410 ton olarak gerçekleşmiş ve bir önceki yıla göre \%115'lik bir artış gerçekleşmiştir (Şekil 2). 2012 yılında ülkemiz pomza üretimin yaklaşık \%20’si Nevşehir'de gerçekleşmiştir. 
Orhan A., Dinçer İ., Akın M., Çoban S.

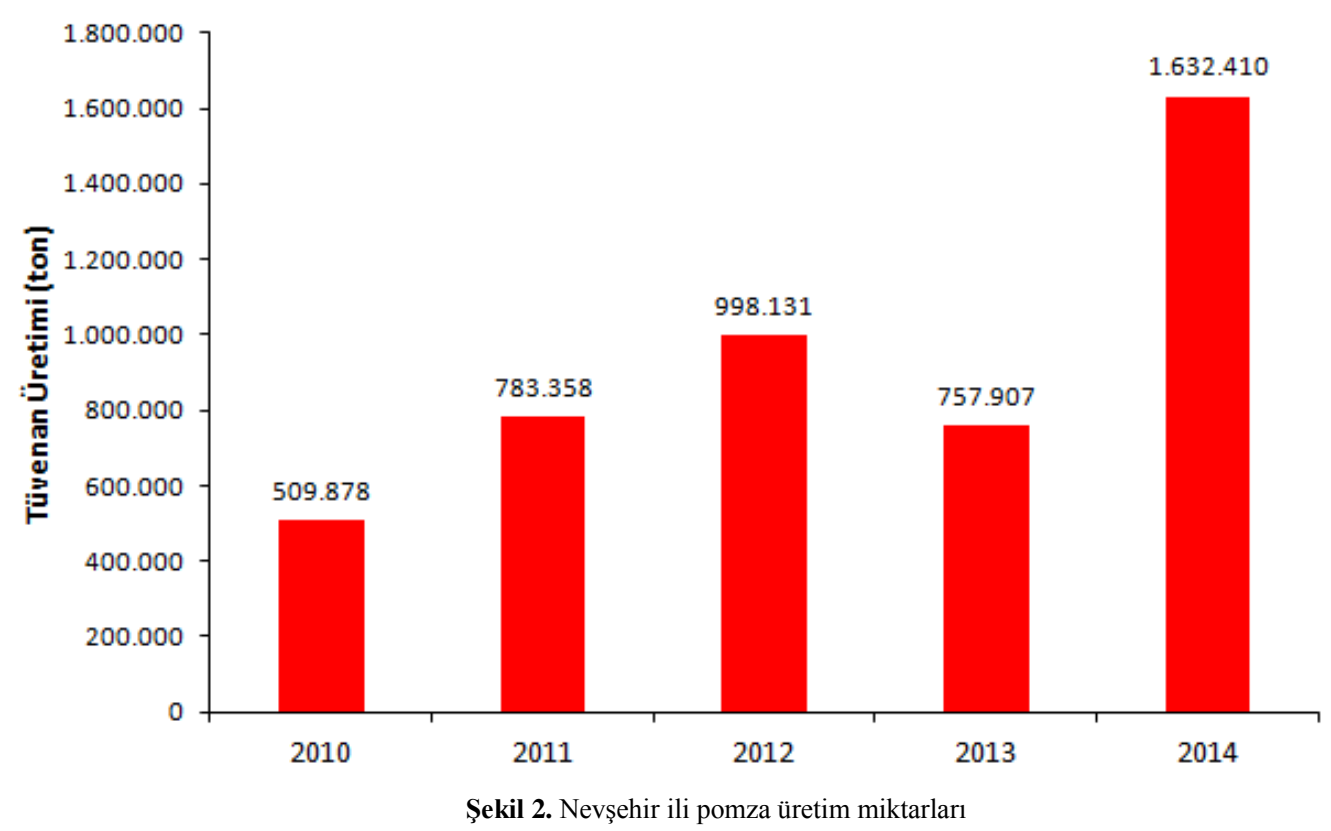

\section{Nevşehir Pomza Sektörü}

Nevşehir pomza sektörünün iktisadi değerlendirilmesi, bu alanda faaliyet gösteren firmalarda anket çalışması ile elde edilen bulgular göz önünde bulundurularak yapılmıştır. Nevşehir ilinde faaliyetini sürdüren 27 firma ile görüşülmüş ve anketler, bu firmaların tamamına ulaştırılmış fakat bazı firmalar anketlere cevap vermek istemediklerini beyan etmişlerdir. Bununla birlikte, anket çalışmasında sektörde ileri gelen firmaların tamamı bulunmaktadır. Bu durum da dikkate alındığında, elde edilen bulguların sektörün geneline 1şık tutacağı görüşünü kuvvetlendirmektedir.

\section{1. Üretim ve Kapasite Oranı}

Firmaların yıllar itibariyle üretimden satışları incelendiğinde, yurtiçi satışların artan bir eğilime sahip olduğu görülmektedir (Şekil 3). 2010 yllında 6.5 milyon TL seviyesinde olan net satışlar 2014 yılında 12.5 milyon TL'ye ulaşmıştır. Sektörün satışları 5 yılda \% 100'lük bir artış göstermiştir. Diğer yandan, yurt dışı satış tutarlarına bakıldığında, son 5 yıllık süreçte giderek azaldığı görülmektedir. Ağırlıklı olarak yurt içi piyasaya yönelik bir sektör görüntüsü sergilemektedir. Bu noktada taşıma maliyetlerinin yüksek olması, ihracat için kalite standartlarının sektörün çok küçük bir kesimi tarafından karşılanıyor olması ve genellikle de inşaat dışında diğer sektörlere sağlanan çıktı oranının düşük kalması, bu sektörün ihracatının düşük seviyelerde seyretmesinin sadece birkaç sebebi olarak ifade edilebilir. 


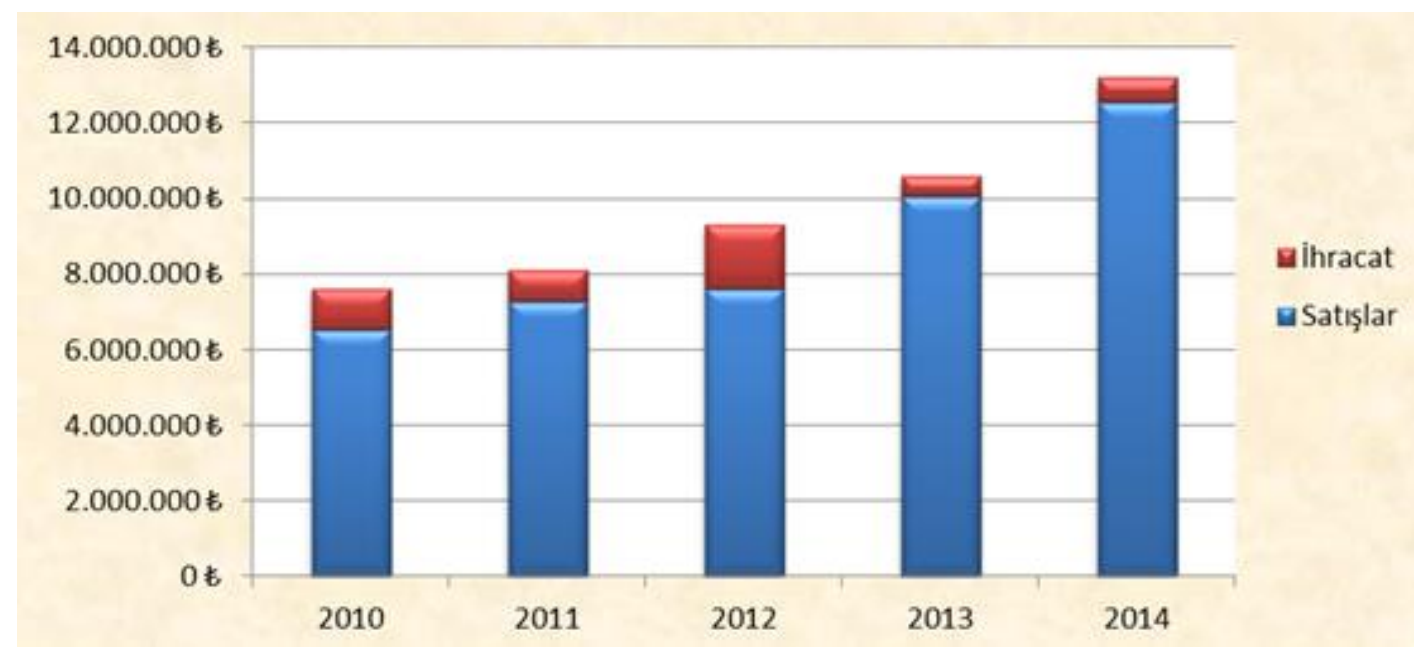

Şekil 3. Yıllara göre net satışlar ve ihracat miktarları

\subsection{Sektörün İstihdam Yapısı}

Sektörde faaliyet gösteren firmaların istihdam durumuna bakıldığında, ankete katılan firmalarda toplamda 614 işçi ve 66 idari personel çalışmaktadır. İşçilerin sadece 6'sının ve idari personelin ise sadece 10’unun bayan olduğu görülmektedir. Sektörün tamamı düşünüldüğünde yaklaşık 1.000 kişi civarında bir istihdam sayısına sahip olduğu tahmin edilmektedir. Firmalarda çalışan personelin eğitim durumuna göre dağılımı Tablo 1'de görüldüğü gibidir. Ağırlıklı olarak lise ve ilkokul mezunu personelin çalıştığı anlaşılmaktadır. Genellikle idari personelin fakülte mezunu olduğu görülmektedir.

Tablo 1. Firmalarda çalışanların eğitim düzeyine göre dağılımı

\begin{tabular}{|c|c|c|c|c|c|}
\hline Personel & İlkokul & Ortaokul & Lise & MYO & Fakülte \\
\hline Vasıfsız Personel (Çırak, İşçi) & 172 & 120 & 115 & 1 & - \\
\hline Üretim Çalışanı (Usta, Kalfa) & 14 & 38 & 92 & 2 & - \\
\hline Teknik Personel (Mühendis, vb.) & - & 13 & 11 & 1 & 6 \\
\hline $\begin{array}{l}\text { İdari Personel } \\
\text { (İK, Pazarlama, Finansman, Muhasebe, vb.) }\end{array}$ & - & 4 & 16 & 9 & 20 \\
\hline TOPLAM & 186 & 175 & 267 & 13 & 26 \\
\hline
\end{tabular}

Pomza sektöründe işgücü temin imkânları açısından değerlendirildiğinde, firmaların eşit oranda zor ve normal düzeyde olduğunu ifade etmeleri dikkati çekmektedir. Firmaların \% 36'sı işgücü temin imkânının zor olduğunu belirtirken, diğer bir \% 36'lık kısım ise normal düzeyde olduğunu ifade etmektedir. İşgücünü temin imkânı son derece zor diyenlerin oranı ise \% 21 olarak gerçekleşmiştir. Zor ve son derece zor diyenlerin toplamı ise \% 57 yapmaktadır. Bu durum, aslında sektörde işgücü teminin oldukça güç olduğunu göstermektedir. Sektörde işgücü temini konusunda en fazla üretim çalışanı konusunda sıkıntı çekildiği ifade edilmektedir (Şekil 4). Firmaların \% 48'i üretim elemanı, \% 24'ü vasıfsız personel olan; çırak ve işçi, \% 16'sı teknik personel ve \% 4'lük dilimler ise ara personel, idari personel ile yönetici temini konusunda güçlük çektiğini göstermektedir. 


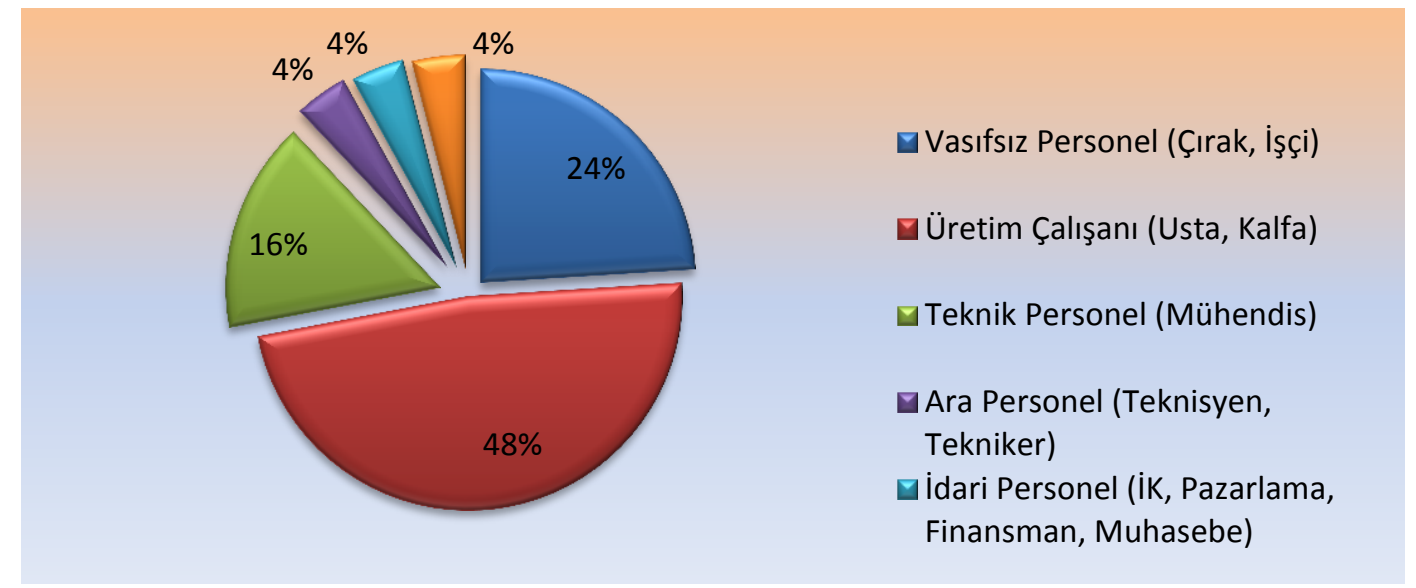

Şekil 4. En çok eksikliği hissedilen eleman türleri

\subsection{Dış Ticaret Durumu}

Sektörün dış ticaret durumu incelendiğinde, ihracatın oldukça düşük olduğu görülmektedir (Şekil 5). Genellikle Suudi Arabistan, Cezayir, Tunus, İngiltere ve Amerika Birleşik Devletleri'nde bimsblok ve pomza ürünlerinin satışı gerçekleştirilmektedir. Ayrıca, firmaların büyük bir çoğunluğu dış ticaret yapmamaktadır. Dış ticaret yapmayan firmaların oranı ise \% 60 gibi küçümsenmeyecek bir seviyededir. Dış ticaret yapanların \% 13’ü, aracı bir dış ticaret şirketi vasıtasılyla ticaretlerini gerçekleştirmektedir. Firmaların \% 13’ü ise, kendi bünyelerinde oluşturdukları dış ticaret bölümleri aracılığıyla dış ticaret faaliyetlerini sürdürmektedir (Şekil 5).

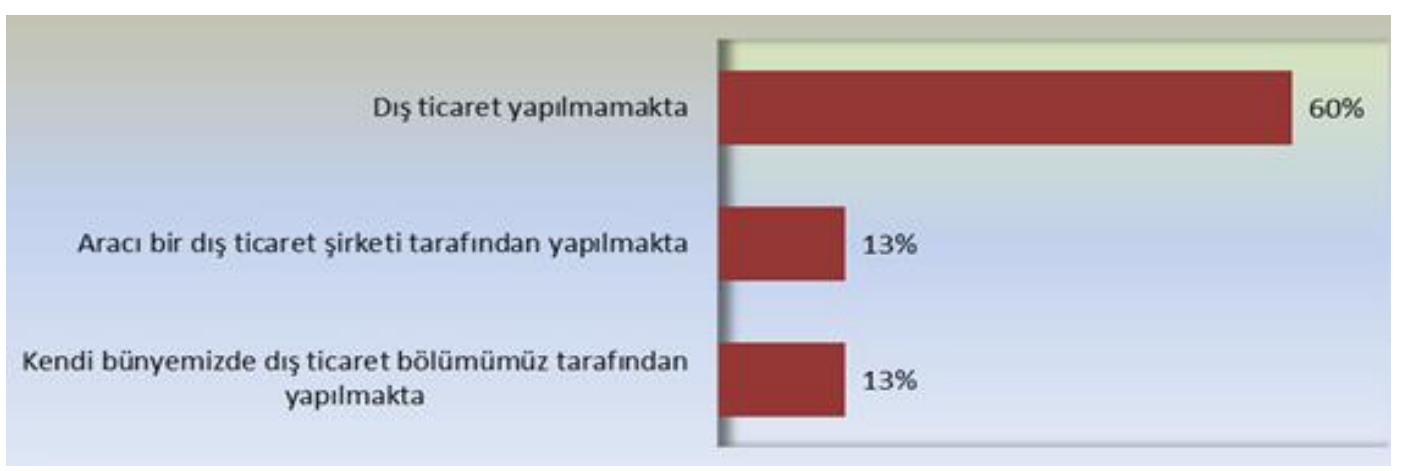

Şekil 5. Firmaların dış ticaret yapma şekli

\subsection{Araştırma Geliştirme Faaliyetleri ve Yenilikçilik}

Son yıllarda her sektörde olduğu gibi pomza sektöründe de rekabetçilik ön plana çıkmaya başlamıştır. Firmaların rekabet gücü kazanabilmesi açısından önemli parametrelerden biri olan araştırma geliştirme faaliyetleri ise, sektörün geneli değerlendirildiğinde oldukça düşük düzeyde kalmaktadır. Araştırma kapsamında olan firmaların \% 40’ı bu konuda herhangi bilgi vermezken, \% 13’ü hiç araştırma geliştirme harcaması yapmadığını ifade etmektedir. Bunun yanında, firmaların \% 47'si araştırma geliştirme harcamalarının \% 1 ile \% 3 arasında yıllık satışlarına katkısı olduğunu belirtmiştir (Şekil 6). Düşük seviyede kalmasına rağmen araştırma geliştirme harcamalarının, toplam satışlar üzerinde olumlu bir etkisinin olduğu söylenebilir. Buradan hareketle araştırma geliştirme faaliyetlerine gereken önemin verilmesi durumunda, satışlarda önemli artışlar kaydedilebilecektir. Araştırma geliştirme faaliyetlerini 
destekleyici projelerin yapılma durumu incelendiğinde, firmaların \% 59'nun hiç proje yapmadığı, buna karşın \% 41'nin en az bir proje yaptığı anlaşılmaktadır. Patent ve faydalı model sayısı konusunda bir değerlendirme yapıldığında, son beş yıllık dönemde hiçbir gelişme olmadığı görülmektedir.

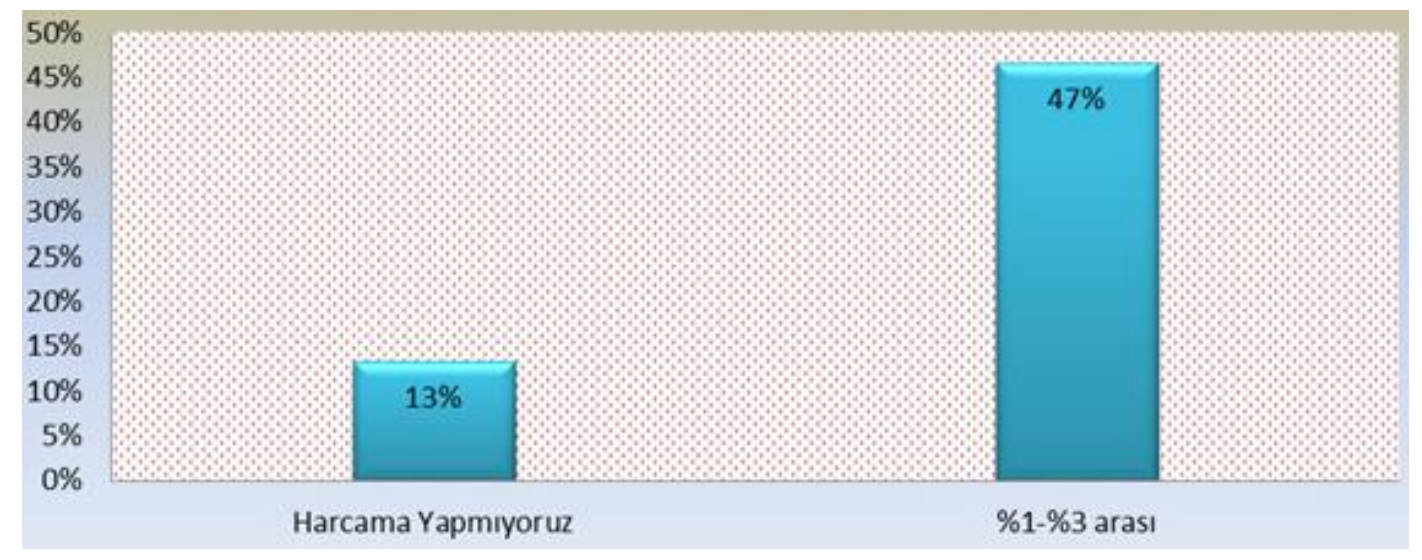

Şekil 6. Ar-Ge harcamalarının yıllık ciroya \% katkısı

\section{5. Üniversite-Sanayi İşbirliği ve Devlet Desteği}

Sektörel gelişmenin sağlanmasında üniversite-sanayi işbirliğinin önemi oldukça büyüktür. Pomza sektöründe faaliyette bulunan firmalar ile üniversite işbirliği üzerine bir değerlendirme yapıldığında, firmaların \% 47'si sektör ve firma açısından işbirliği düzeyinin son derece yetersiz olduğu görüşündedir. Firmaların \% 33'ü sektör açısından ve \% 40’1 ise firma açısından işbirliği düzeyinin yetersiz olduğunu belirtmektedir. Küçük bir kesim ise üniversite-sanayi işbirliği düzeyinin normal düzeyde olduğunu ifade etmektedir. Diğer yandan sektöre yapılan destekler dikkate alındığında ise, en büyük desteğin \% 80'nin üzerinde bir oran ile KOSGEB tarafından sağlandığı görüşü ortaya çıkmaktadır. Daha sonra ikinci sırada ise \% 60'lı bir oran ile Ahiler Kalkınma Ajansı yer almaktadır. TÜBİTAK desteklerinin ise düşük kaldığı göze çarpmaktadır.

\section{Tartışma ve Sonuçlar}

Ülkemizde üretimi ve ihracatı sürdürülen pomza sektörünün mevcut ve ileride ortaya çıkabilecek üretim, araştırma, yatırım ve pazarlama ile ilgili sorunları önerileri ile birlikte aşağıda irdelenmiştir. Sorunların tespiti noktasında yapılan incelemelerden ve görüş alışverişlerinin yanı sıra konu ile ilgili yapılan önceki çalışmalardan faydalanılmıştır.

Öncelikle Nevşehir bölgesi pomza açısından yüksek bir rezerve sahip olmasına rağmen nihayetinde pomza doğada sınırı bir şekilde bulunmaktadır. Bundan dolayı, firmaların mevcut kaynakları kontrolsüz bir şekilde kullanması ve geleneksel üretim teknik ve süreçleriyle bimsblok üreticiliğine devam etmesi durumunda, uzun vadede firmaların faaliyetlerine devam etmesi mümkün görünmemektedir. Bu nedenle firmaların araştırma geliştirme çalışmalarına bütçe ayırmak suretiyle katma değeri yüksek ürünleri üretmeleri gerekmektedir. Böylece hem firma açısından hem de ülke ekonomisi açısından pomza sektöründe farklı bir boyuta geçilmiş olacaktır.

Pomza madeninin üretimi esnasında rastgele bir çalışma metodu hâkimdir. Hafriyatçıllktan bir an önce vazgeçilerek madencilik metotlarının uygulanması muhakkak temin edilmeli, cevher kaybı 
asgariye indirilerek, bilimsel işletme metotları titizlikle uygulanarak verim artışı sağlanmalıdır. $\mathrm{Bu}$ aşamaya gelebilmek için, vakit kaybetmeksizin ilgili kişi, kurum ve kuruluşlardan, bilimsel ve teknik yardım talebinde bulunulmalı, işletme projeleri sağlıklı olarak geliştirilmeli, teknik personel istihdamına önem verilmelidir.

Pomzanın yaygın kullanım alanının olması dikkate alındığında, bu ürüne yönelik talebin gelecekte artacağı öngörülmektedir. Pomza kaynaklarının en verimli şekilde üretimde kullanılması ve katma değerinin yükseltilmesi, bu sektörün karlılığını da arttıracaktır.

Araştırma ve geliştirme faaliyetleri her sektörde olduğu gibi bu sektörde de ciddi maliyet yaratan ve geri dönüşümü uzun süren bir faaliyettir. $\mathrm{Bu}$ maliyetlerin karşılanmasında iç fonlar yeterli gelmeyebilir. Nevşehir ilinde faaliyet gösteren firmaların araştırma geliştirme faaliyetlerinde bulunabilmeleri için uzun vadeli fonlara yönelmeleri, bu konudaki finansman ihtiyaçlarını karşılayabilecektir. Ayrıca bu konuda üreticilerin cesaretlendirilmesi ve yönlendirilmesi gerekmektedir.

Pomzadan elde edilen ürünlerinde standardizasyon ve kalibrasyon olmaması nedeniyle üretici ile tüketici arasında problemler yaşanmaktadır. Üretimde gerekli alt yapı ve teknolojik yatırımlara gidilerek standardizasyon ve kalibrasyon sağlanmalı, kaliteye özen gösterilmelidir. Oluşturulacak standartlarda tüketici talepleri mutlaka dikkate alınmalıdır.

Sektör paydaşlarının belirttiğine göre, ciddi pomza rezervine sahip olmalarına rağmen bazı ülkelerin ülkemizden pomza ihraç rakamları her geçen gün artmaktadır. Söz konusu ülkelerin, Türk pomzasının ambalajını yenileyerek dünya pazarlarına kendi isimleriyle sürdürdükleri ve bu işten büyük kazançlar sağladıkları görülebilmektedir. Bundan dolayı pomzanın yurtdışına hammadde olarak çıkmasının önüne geçilmelidir. Hammadde ihracından ziyade, üniversite - sanayi işbirliği geliştirilerek mamul ürün yatırım imkânları araştırılmalı ve hayata geçirilmelidir.

Pomza üretici ve ihracatçıları, başta pazarlama konusunda olmak üzere her konuda daha bilinçli davranmaları gerekmektedir. Geleneksel yöntemlerden uzaklaşarak, günümüzün etkili iletişim kanallarını daha yoğun kullanmalıdır. Her türlü yeniliğe açık bir pozisyon almaları, hem bölge hem de ülke ekonomisi için büyük önem arz etmektedir.

Sektörün yaşamakta olduğu diğer önemli bir sorun ise kendi aralarındaki haksız rekabettir. Ülke içindeki üretici ve ihracatçıların yeteri kadar ortak hareket etmemesi, birbirleri ile rekabet ortamı yaratmaları, gerçek madencilik bilincinden yoksun ilkel üretim anlayışı sektörün genişlemesini zorlaştırmaktadır.

Yukarıda geniş bir şekilde değinilen sorunları maddeleştirerek vermek gerekirse, aşağıda belirtilen şu sorunlar öne çıkmaktadır.

- Ürün standardizasyonu ve kalite anlayışının yerleşmemiş olması,

- Pazarlama ve tanıtım konusunda bilinçli davranılmaması,

- Üniversite - sanayi işbirliğinin yok denilecek kadar az olması,

- Ar-Ge çalışmalarına önem verilmemesi ve maliyetlerinin çok yüksek olması,

- Maden üretimi konusunda rastgele bir çalışma metodunun hâkim olması,

- Kalifiye eleman eksikliği,

- Haksız rekabet sebebiyle belirli bir fiyat politikası uygulanamaması ve birim fiyatların düşmesi, 
- Nakliye giderlerinin oldukça fazla olması,

- Ortak hareket etme kültürünün yetersizliği,

- Katma değeri düşük ürünlerin sektöre hâkim olması öne çıkan başlıca sorunlardır.

\section{Teşekkür}

Bu çalışma Ahiler Kalkınma Ajansının destekleri kapsamında yapılmış olup, bu desteklerinden dolayı yazarlar Ahiler Kalkınma Ajansı’na ve çalışanlarına ve değerli görüşlerinden dolayı Prof. Dr. Lütfullah GÜNDÜZ’e ve Nevşehir pomza sektöründe faaliyet gösteren firmalara yapmış oldukları paylaşımlardan dolayı teşekkür ederler.

\section{Kaynaklar}

[1] Erdoğan Y., “Asidik ve Bazik Pomzadan Üretilen Yap1 Malzemelerinin Mühendislik Özelliklerinin Araştırılması” Çukurova Üniversitesi Fen Bilimleri Enstitüsü, Doktora Tezi, 300 s, Adana, 2010

[2] Gündüz L., “İnşaat Sektöründe Bimsblok” Süleyman Demirel Üniversitesi Yayınları, 928 s., Isparta, 2005

[3] MTA, "Nevşehir İli Maden ve Enerji http://www.mta.gov.tr/v1.0/turkiye_maden/maden_potansiyel_2010/Nevsehir_Madenler.pdf, 2010

[4] MİGEM, Maden Işsleri Genel Müdürlüğü Kayıtlarl, 2014 